\title{
Ficus (Moraceae) and fig wasps (Hymenoptera: Chalcidoidea) in Taiwan
}

\author{
Anthony Bain ${ }^{1,2}$, Hsy-Yu Tzeng ${ }^{3}$, Wen-Jer Wu ${ }^{4}$ and Lien-Siang Chou ${ }^{1 *}$
}

\begin{abstract}
Although Ficus-associated wasp fauna have been extensively researched in Australasia, information on these fauna in Taiwan is not well accessible to scientists worldwide. In this study, we compiled records on the Ficus flora of Taiwan and its associated wasp fauna. Initial agronomic research reports on Ficus were published in Japanese in 1917, followed by reports on applied biochemistry, taxonomy, and phenology in Chinese. On the basis of the phenological knowledge of 15 species of the Ficus flora of Taiwan, recent research has examined the pollinating and nonpollinating agaonid and chalcid wasps (Hymenoptera: Chalcidoidea). Updating records according to the current nomenclature revealed that there are 30 taxa (27 species) of native or naturalized Ficus with an unusually high proportion of dioecious species (78\%). Four species were observed to exhibit mutualism with more than one pollinating wasp species, and 18 of the 27 Ficus species were reported with nonpollinating wasp species. The number of nonpollinating wasp species associated with specific Ficus species ranges from zero (F. pumila) to 24 (F. microcarpa). Approximately half of the Taiwanese fig tree species have been studied with basic information on phenology and biology described in peer-reviewed journals or theses. This review provides a solid basis for future in-depth comparative studies. This summary of knowledge will encourage and facilitate continuing research on the pollination dynamics of Ficus and the associated insect fauna in Taiwan.
\end{abstract}

Keywords: Chalcidoidea; Ficus; Fig wasp; Nomenclature; Taiwan

\section{Review}

Introduction

The pantropical genus Ficus (Moraceae) is the most speciose genus of woody plants, comprising 735 species known worldwide (Berg and Corner 2005). Ficus is characterized by their unique inflorescences, called figs, or syconia. Due to their essential role in tropical landscapes and their rich ecological relationships with numerous invertebrates and vertebrates, fig trees may be considered as keystone resources of tropical forests (Shanahan et al. 2001; Harrison 2005). Asia contains a wide diversity of Ficus flora, with 130 known species from Borneo (Berg and Corner 2005), 99 from China (Wu et al. 2003) and only 25 species common to the two areas.

The genus has attracted considerable attention among ecologists because of its obligate mutualism with pollinating wasps (Hymenoptera: Agaonidae: Agaoninae,

\footnotetext{
* Correspondence: chouls@ntu.edu.tw

${ }^{1}$ Institute of Ecology and Evolutionary Biology, College of Life Science,

National Taiwan University, No. 1, Sec. 4, Roosevelt Rd., Taipei 10617, Taiwan Full list of author information is available at the end of the article
}

Kradibiinae, Tetrapusiinae) (Cruaud et al. 2010; Heraty et al. 2013). Fig trees have become an essential model for studies on mutualism (Janzen 1979; Frank 1985), sex ratio theory (Herre 1985; Weiblen 2002), and coevolution processes (Anstett et al. 1997; Cook and Rasplus 2003).

Fig trees and their pollinators have long been used as an example of obligate mutualism. The pollinating wasps are the only organism pollinating the figs and these wasps can only lay eggs in fig ovules. The pollinators enter into the fig by a tight ostiole. Once inside the fig, wasps pollinate the flowers and lay eggs inside the fig ovules (Kjellberg et al. 2005). Then the larvae feed on gall tissue induced during the oviposition and mature along with the seeds and pollen grains of the fig. At maturity, fertilized female pollinating wasps leave the natal fig and transport pollen to another receptive fig on another tree (Kjellberg et al. 2005). Some pollinating fig wasps genera actively pollinate the styles of the ovules before oviposition. After mating, they open the anthers of their natal fig and collect pollen grains that are stored

\section{Springer}

(c) 2015 Bain et al.; licensee Springer. This is an Open Access article distributed under the terms of the Creative Commons Attribution License (http://creativecommons.org/licenses/by/4.0), which permits unrestricted use, distribution, and reproduction in any medium, provided the original work is properly credited. 
in pollen pockets located on the ventral side of the mesosoma (Kjellberg et al. 2001). In contrast, passive pollination requires no specific behavior: The pollen grains simply stick to the wasp body and fertilize ovules when the pollinating wasps enter a fig. Though one Ficus species is associated with only one pollinating wasp species in most of the cases (Janzen 1979), some Ficus species have long been known to host additional pollinating wasp species (Galil and Eisikowitch 1967; Ramírez 1970; Molbo et al. 2003).

In addition to the pollinating wasp species, most of the Ficus species also host nonpollinating wasp species (Kjellberg et al. 2005). These wasps oviposit from the outside of the figs. The number of nonpollinating wasps (NPFW) species varies greatly between Ficus species (Kerdelhué et al. 2000). Their feeding regimes also vary: Some NPFW species gall the ovules similarly to the pollinating species, and some are parasitoids (Compton and van Noort 1992).

Over the past century, extensive research on various characteristics of the fig flora in Taiwan and its associated fauna has been conducted (Figure 1). Taiwan and its offshore islands are tropical and subtropical. Recently, 26 native and one introduced Ficus species have been reported (Tzeng 2004, in Chinese with English abstract). The first report on the Ficus genus in Taiwan was written in Japanese and focused on the cultivation of Ficus pumila var. awkeotsang (Takao 1917). The first taxonomic monograph was published in 1934. (Sata 1934), followed 10 years later, by a comparison of the fig flora in Taiwan and in the Philippines (Sata 1944). Later on, several studies addressing the biochemistry of an edible jelly produced from the dried seeds of $F$. pumila var. awkeotsang (Huang and Chen 1979; Huang et al. 1980; Lin et al. 1989; Liu et al. 1989, 1990) were published. This jelly, locally called "aiyu", is a common ingredient of summer beverages in Taiwan.

Taxonomic research on the Ficus genus in Taiwan resumed 45 years after Sata's final publication (Liao 1989), which has been recently updated by Tzeng (2004). The research performed by Tzeng (2004) is exhaustive and provides a clear understanding of the Ficus flora and its distribution around Taiwan.

The phenology of Ficus has been extensively studied (Hu et al. 1986; Ho 1987). Phenological research introduced a physiological point of view to the study of fig ecology. However, common fig-wasp interactions have rarely been reported in Taiwan. We here establish a framework for future work on Taiwan Ficus and its associated wasp fauna by providing an updated list of Ficus species and the associated wasp species in Taiwan. These wasp species include specific pollinators or groups of pollinator species (in a few cases) as well as nonpollinating fig wasps.

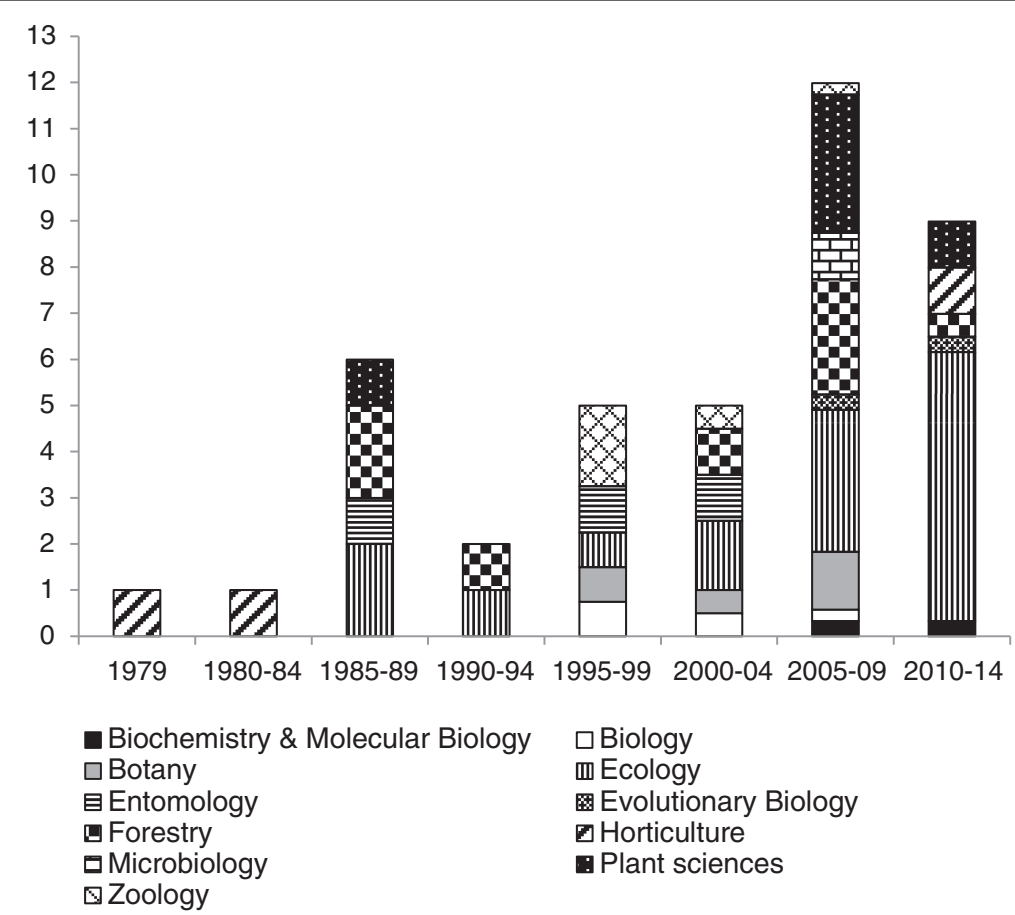

Figure 1 Taiwanese publications on fig and fig wasps since 1979. Each Taiwanese article has been classified under a discipline in which the journal they have been published in. The categories are the ones used in the ISI Web of Knowledge ${ }^{\text {SM }}$. Nevertheless 18 of the 24 cited journals were not referenced by ISI Web of Knowledge ${ }^{S M}$ then they have been categorized according to the journal description. For the journals having more than one category, value has been divided in equal parts. For example, a journal categorized in Forestry and Ecology would have counted as 0.5 in the two categories for this graph. 
As part of a previous field study (Bain 2012), we collected figs from various sites throughout a lowland forest habitat on Taiwan as well as on Orchid and Green Islands off the southeast coast of Taiwan.

\section{Notes on the taxonomy of Ficus (Moraceae)}

In this present review, historical records were updated according to the current taxonomy and nomenclature guidelines to list 27 fig species (one species more than previously recorded) and 30 distinct taxa associated with the six subgenera present in Taiwan: Urostigma (5 taxa), Pharmacosycea (2), Ficus (8), Synoecia (6), Sycidium (6), and Sycomorus (3) (Table 1).

Several species names from the studies of Liao (1989, 1995) and Tzeng (2004) were updated according to the recent taxonomic and nomenclatural knowledge. In the subgenus Urostigma, F. subpisocarpa has been subject to two recent revisions. Berg and Corner (2005) reinstated the species from F. superba var. japonica. Subsequently, by incorporating new observations from Thailand, Berg further divided the species into two subspecies: F. subpisocarpa subsp. pubipoda and F. subpisocarpa subsp. subpisocarpa (Berg 2007). Based on this knowledge, the Taiwanese taxon is F. subpisocarpa subsp. subpisocarpa (hereafter called F. subpisocarpa). Several taxonomic questions for this subgenus group remain unanswered. For example, the taxonomic position of F. benjamina var. bracteata is unclear. In 1983, Yamazaki described F. benjamina var. bracteata from Taiwan for the first time; subsequently, Berg and Corner (2005) assigned it a synonym: $F$. benjamina. In the studies conducted by Berg and Corner (2005) and Corner (1965), the analyzed F. benjamina var. bracteata samples were not obtained from Taiwan. Our observations from southern Taiwan reveal differences between $F$. benjamina var. benjamina and F. benjamina var. bracteata (Bain and Tzeng, pers. obs.). Despite these differences, until further research provides a new basis for a decision, we continue to list F. benjamina var. bracteata as a variety according to descriptions provided by Tzeng (2004). In addition, F. religiosa was not listed as a native species in the report of Sata (1934), but as introduced to Taiwan. Nevertheless, because the pollinating wasp species of $F$. religiosa, Platyscapa quadraticeps, has been observed in Taiwan, we consider F. religiosa a naturalized species (Chen and Chou 1997).

Two previously reported species of the subgenus Pharmacosycea from Taiwan have been reported ( $F$. nervosa subsp. nervosa and F. nervosa subsp. pubinervis) have a debatable taxonomic status. Tzeng (2004) considered the aforementioned species as two distinct species whereas Berg and Corner (2005) listed them as subspecies. Both species are allopatric: F. nervosa subsp. nervosa is distributed in southern Taiwan and F. nervosa subsp. pubinervis is distributed only in Orchid Island (the island, located offshore on the Southeast of Taiwan Island, is also called Lanyu, $22^{\circ} 03^{\prime} \mathrm{N}$; $121^{\circ} 32^{\prime} \mathrm{E}$ ) ('Tzeng 2004). The fact that they are pollinated by different agaonid wasp species (Table 1) provides additional evidence for distinguishing them as different species. According to pollen, pyrena and leaf morphology evidence (Chuang 2000; Tzeng 2004; Tzeng et al. 2009), F. nervosa subsp. nervosa and F. nervosa subsp. pubinervis are phylogenetically close, yet distinct species. Thus, in this study, we refer to F. nervosa subsp. nervosa and F. nervosa subsp. pubinervis as F. nervosa and F. pubinervis, respectively.

In the subgenus Sycidium, F. tinctoria subsp. swinhoei has been synonymized under $F$. tinctoria subsp. tinctoria (Berg and Corner 2005). The distribution of the former taxon is limited to southern Taiwan and Orchid Island, whereas F. tinctoria is widely distributed throughout Australasia (Berg and Corner 2005). Moreover, these two subspecies have different pollinators (J-Y Rasplus, pers. obs.). Therefore, on the basis of the study by Tzeng (2004), we continue to list F. tinctoria subsp. swinhoei as separated from F. tinctoria subsp. tinctoria. Ficus tinctoria and $F$. virgata are two species that require further taxonomic investigation. After solely studying herbarium samples, Berg and Corner (2005) could not clearly distinguish between Taiwanese F. tinctoria and F. virgata. However, according to local field observations, $F$. virgata can be clearly and unambiguously distinguished from other Ficus species (Liao 1989, 1995; Tzeng 2004). Thus, Taiwanese F. virgata and F. tinctoria subsp. swinhoei are here considered distinct species.

Furthermore, in the subgenus Ficus, F. esquiroliana has been synonymized under $F$. triloba subsp. triloba (Berg 2007). We support this decision because we found morphologically similar trees in Yunnan, China, and Taiwan (Bain and Tzeng, pers. obs.).

In addition, F. benguetensis (subgenus Sycomorus) has been reinstated as a full species (Tzeng 2004; Berg and Corner 2005). Previously, F. benguetensis was considered a variety, F. fistulosa var. benguetensis (Liao 1989, 1995); in addition, Berg (2011) amended its description.

Finally, F. aurantiacea var. parvifolia (subgenus Synoecia) has been synonymized under F. punctata (Berg and Corner 2005). Two forms of F. aurantiacea var. parvifolia have been described. The taxon distributed in Taiwan is listed under the "aurantiacea form" (i.e., F. punctata f. aurantiacea) (Chou and Yeh 1995).

Morphological studies have facilitated the confirmation of the classification of Taiwanese Ficus (Shieh 1964; Chuang 2000; Tseng et al. 2000; Bai 2002; Chuang et al. 2005; Chang et al. 2009; Tzeng et al. 2001, Tzeng et al. 2005b, Tzeng et al. 2006a, Tzeng et al. 2009). Among these studies, pollen (Tzeng et al. 2009) and pyrena (Chuang 2000; Chuang et al. 2005; Tzeng et al. 2006a) morphologies 
Table 1 Taiwan Ficus taxa and their associated pollinating and non-pollinating wasp species

\begin{tabular}{|c|c|c|}
\hline Ficus & Fig wasps & References \\
\hline \multicolumn{3}{|c|}{ Subgenus Urostigma (monoecious) } \\
\hline \multirow{3}{*}{$\begin{array}{l}\text { F. benjamina L. var. bracteata } \\
\text { Corner }\end{array}$} & Eupristina koninsbergeri ${ }^{P_{*}}$ & Grandi 1916 \\
\hline & Philotrypesis distallatoria & Grandi 1926; Chou and Wong 1997 \\
\hline & Micranisa sp1 Sycoryctini sp. & Bain A. unpublished data; Segar et al. 2012 \\
\hline \multirow[t]{4}{*}{ F. caulocarpa Miq. } & Platyscapa fischeri ${ }^{P_{*}}$ & Wiebes 1977; Yokoyama and Iwatsuki 1998 \\
\hline & Platyscapa hsui ${ }^{P}$ & Chen and Chou 1997 \\
\hline & Camarothorax sp2* & Yokoyama and Iwatsuki 1998 \\
\hline & Otitesella clarae* & Wiebes 1977; Yokoyama and Iwatsuki 1998 \\
\hline \multirow[t]{23}{*}{ F. microcarpa L. f. } & Eupristina verticillata $^{P}$ & Waterston 1921; Chen and Chou 1997 \\
\hline & Walkerella kurandensis & Bouček 1988; Chen et al. 1999 \\
\hline & Walkerella microcarpae & Bouček 1993; Yang H-W unpublished data \\
\hline & Acophila microcarpa & Chen et al. 1999 \\
\hline & Bruchophagus sensoriae & \\
\hline & Meselatus bicolor & \\
\hline & Micranisa degastris & \\
\hline & Ormyrus lini & \\
\hline & Philotrypesis taiwanensis & \\
\hline & Sycophila curta & \\
\hline & Sycophila maculafacies & \\
\hline & Sycophila petiolata & \\
\hline & Sycoryctes moneres & \\
\hline & Odontofroggatia quinifuniculus & Feng and Huang 2010; Yang H-W unpublished data \\
\hline & Philotrypesis emeryi & Grandi 1926; Chen et al. 1999 \\
\hline & Eufroggattisca okivanensis & Ishii 1934; Chen et al. 1999 \\
\hline & Odontofroggatia gajimaru & \\
\hline & Philotrypesis okinavensis & \\
\hline & Sycoscapter gajimaru & \\
\hline & Micranisa yashiroi* & Ishii 1934; Yokoyama and Iwatsuki 1998; Beardsley 1998 \\
\hline & Conidarnes sp1 & Cruaud et al. 2011 \\
\hline & Odontofroggatia corneri & Wiebes 1980; Chen et al. 1999 \\
\hline & $\begin{array}{l}\text { Odontofroggatia galili } \\
\text { Odontofroggatia ishii }\end{array}$ & \\
\hline F. subpisocarpa Gagnep. & Platyscapa ishiiana ${ }^{P}$ & Grandi, 1923; Chen and Chou, 1997 \\
\hline \multirow[t]{6}{*}{ subsp. subpisocarpa Corner } & Otitesella ako & Ishii, 1934; Bain A. unpublished data \\
\hline & Acophila mikii & \\
\hline & Philotrypesis sp $1^{*}$ & Yokoyama and Iwatsuki 1998 \\
\hline & Sycoscapter sp $1^{*}$ & \\
\hline & Camarothorax sp1* & \\
\hline & Camarothorax sp2, sp3 & Bain A. unpublished data \\
\hline F. subpisocarpa Gagnep. & Micranisa sp1 & Bain A. unpublished data \\
\hline subsp. subpisocarpa & Ormyrus sp1, sp2 & \\
\hline \multirow[t]{3}{*}{ Corner } & Philotrypesis sp1 & \\
\hline & Sycophila sp1, sp2, sp3, sp4, sp5 & \\
\hline & Walkerella sp1 & \\
\hline
\end{tabular}


Table 1 Taiwan Ficus taxa and their associated pollinating and non-pollinating wasp species (Continued)

\begin{tabular}{|c|c|c|}
\hline & Arachonia sp1 & Cruaud et al. 2011; Segar et al. 2012; Bain A. unpublished data \\
\hline & Sycoryctes sp1 & \\
\hline & Sycoscapter sp2 & \\
\hline \multirow[t]{6}{*}{ F. religiosa L. } & Platyscapa quadraticeps ${ }^{p}$ & Mayr 1885; Chen and Chou 1997 \\
\hline & Otitesella digitata* & Westwood 1883; Wiebes 1966 \\
\hline & Otitesella religiosa* & \\
\hline & Sycoscapter gracilipes* & \\
\hline & Sycoscapteridea monilifera* & \\
\hline & Philotrypesis anguliceps* & Westwood 1883; Wiebes 1966; Bouček 1988 \\
\hline \multicolumn{3}{|l|}{ Subgenus Ficus (dioecious) } \\
\hline \multirow{2}{*}{$\begin{array}{l}\text { F. erecta Thunb. var. beecheyana } \\
\text { King }\end{array}$} & Blastophaga nipponica ${ }^{\mathrm{P}}$ & Grandi 1921; Chen and Chou 1997 \\
\hline & Sycoscapter inubiae, sp 1 & Ishii 1934; Tzeng et al. 2006b, Tzeng et al. 2008 \\
\hline \multirow[t]{2}{*}{ F. formosana Maxim. } & Blastophaga taiwanensis $^{\mathrm{P}}$ & Chen and Chou 1997 \\
\hline & Sycoscapter sp1, sp2 & Tzeng et al. 2008 \\
\hline \multirow{2}{*}{$\begin{array}{l}\text { F. pedunculosa Miq. var. } \\
\text { pedunculosa }\end{array}$} & Blastophaga peducunlosae $e^{p}$ & Chen and Chou 1997 \\
\hline & (Parasitic fauna unknown) & \\
\hline \multirow{2}{*}{$\begin{array}{l}\text { F. pedunculosa Miq. var. mearnsii } \\
\text { Corner }\end{array}$} & Blastophaga peducunlosae $e^{p}$ & Chen and Chou 1997 \\
\hline & Apocrypta sp. & Bain, unpublished data \\
\hline \multirow[t]{2}{*}{ F. ruficaulis Merr. } & Valisia filippina $^{P}$ & Wiebes 1993; Chen and Chou 1997; Cruaud et al. 2010 \\
\hline & (Parasitic fauna unknown) & \\
\hline F. tannoensis Hay. & Blastophaga tannoensis $^{P}$ & Chen and Chou 1997 \\
\hline \multirow{2}{*}{$\begin{array}{l}\text { F. triloba Buch.-Ham. subsp. triloba } \\
\text { Corner }\end{array}$} & Valisia esquirolianae $^{\mathrm{p}}$ & Chen and Chou 1997; Cruaud et al. 2010 \\
\hline & Sycoryctini sp. & Segar et al. 2012; Bain A. pers. obs. \\
\hline \multirow[t]{2}{*}{ F. vaccinoides Hemsl. } & Blastophaga yeni $i^{P}$ & Chen and Chou 1997 \\
\hline & (Parasitic fauna unknown) & \\
\hline \multicolumn{3}{|l|}{$\begin{array}{l}\text { Subgenus Pharmacosycea } \\
\text { (monoecious) }\end{array}$} \\
\hline \multirow[t]{3}{*}{ F. nervosa subsp. nervosa Heyne } & Dolichoris nervosae nervosae ${ }^{P_{*}}$ & Hill 1967 \\
\hline & Philotrypesis sp1 & \\
\hline & Sycoscapter sp1 & \\
\hline \multirow[t]{2}{*}{ F. nervosa subsp pubinervis Blume } & Dolichoris valentine $e_{*}^{P_{*}}$ & Grandi 1916 \\
\hline & (Parasitic fauna unknown) & \\
\hline \multicolumn{3}{|l|}{ Subgenus Synoecia (dioecious) } \\
\hline \multirow[t]{3}{*}{ F. pumila L. var. pumila } & Wiebesia pumilae ${ }^{p}$ & Hill 1967; Chen and Chou 1997 \\
\hline & Wiebesia sp. ${ }^{P}$ & Wang et al. 2013 \\
\hline & No parasitic wasp in Taiwan & \\
\hline \multirow{3}{*}{$\begin{array}{l}\text { F. pumila L. var. awkeotsang } \\
\text { Corner }\end{array}$} & Wiebesia pumilae $^{\mathrm{P}}$ & Hill 1967 \\
\hline & Wiebesia sp. ${ }^{p}$ & Wang et al. 2013 \\
\hline & No parasitic wasp in Taiwan & \\
\hline \multirow{2}{*}{$\begin{array}{l}\text { F. punctata Thunb. f. aurantiacea } \\
\text { Corner }\end{array}$} & Wiebesia contubernalis ${ }^{\mathrm{P}}$ & Grandi 1927a; Chen and Chou 1997 \\
\hline & Sycoscapter sp. & Chou and Yeh 1995 \\
\hline
\end{tabular}


Table 1 Taiwan Ficus taxa and their associated pollinating and non-pollinating wasp species (Continued)

\begin{tabular}{|c|c|c|}
\hline F. sarmentosa Buch.-Ham. & Wiebesia callida $^{\mathrm{P}}$ & Grandi 1927a; Chen and Chou 1997 \\
\hline var. nipponica Corner & (Parasitic fauna unknown) & \\
\hline \multirow[t]{2}{*}{ F. trichocarpa Blume } & Wiebesia vechti ${ }^{\mathrm{P}}$ & Wiebes 1993 \\
\hline & (Parasitic fauna unknown) & \\
\hline \multicolumn{3}{|c|}{ Subgenus Sycidium (dioecious) } \\
\hline \multirow[t]{5}{*}{ F. ampelas Burm. f. } & Krabidia sumatrana ${ }^{P}$ & Wiebes 1993; Chen and Chou, 1997 \\
\hline & Philotrypesis distallatoria & Grandi 1926; Chang 2003 \\
\hline & Philotrypesis jacobsoni & Grandi 1926; Chou and Wong 1997 \\
\hline & Sycoryctes sp1, sp2 & Chang 2003 \\
\hline & Epichrysomallinae sp. & \\
\hline \multirow[t]{2}{*}{ F. cumingii Miq. } & Krabidia panchoi $^{\mathrm{P}}$ & Wiebes 1993; Chen and Chou 1997 \\
\hline & (Parasitic fauna unknown) & \\
\hline \multirow[t]{2}{*}{ F. heteropleura Blume } & Krabidia dubium $^{p_{*}}$ & Grandi 1926; Cruaud et al. 2010 \\
\hline & (Parasitic fauna unknown) & \\
\hline \multirow[t]{5}{*}{ F. irisana Elm. } & Krabidia commuta ${ }^{P}$ & Wiebes 1993; Chen and Chou 1997 \\
\hline & Herodotia sp. & Chen 1998 \\
\hline & Philotrypesis sp1, sp2 & \\
\hline & Sycophila sp1, sp2 & \\
\hline & Sycoscapter sp. & \\
\hline \multirow{7}{*}{$\begin{array}{l}\text { F. tinctoria G. Forst. subsp. } \\
\text { swinhoei King }\end{array}$} & Krabidia gibbosae & Hill 1967; Chen and Chou 1997; Cruaud et al. 2010 \\
\hline & Neosycophila sp. & Huang 2007 \\
\hline & Philotrypesis sp1, sp2 & \\
\hline & Sycoscapter sp. & \\
\hline & Eufroggatisca sp. & Tzeng H-Y unpublished data \\
\hline & Sycoryctes sp. & \\
\hline & Sycophila sp. & \\
\hline \multirow[t]{3}{*}{ F. virgata Reinw. } & Krabidia philippinensis ${ }^{\mathrm{P}}$ & Hill 1969; Chen and Chou 1997; Cruaud et al. 2010 \\
\hline & Krabidia virgatae ${ }^{P_{*}}$ & Hill 1969; Cruaud et al. 2010 \\
\hline & Krabidia sessilis ${ }^{P_{*}}$ & \\
\hline \multirow[t]{3}{*}{ F. virgata Reinw. } & Camarothorax sp. & Bain A. unpublished data \\
\hline & Philotrypesis sp. & \\
\hline & Sycoryctini sp. & Segar et al. 2012; Bain A. unpublished data \\
\hline \multicolumn{3}{|c|}{ Subgenus Sycomorus (dioecious) } \\
\hline \multirow[t]{3}{*}{ F. benguetensis Merr. } & Ceratosolen wui ${ }^{p}$ & Chen and Chou 1997 \\
\hline & Philotrypesis sp1, sp2 & Bain A. unpublished data \\
\hline & Sycoscapter sp1, sp2 & \\
\hline \multirow[t]{8}{*}{ F. septica Burm. } & Ceratosolen bisulcatus bisulcatus ${ }^{P_{*}}$ & Mayr 1885; Wiebes 1994 \\
\hline & Ceratosolen bisulcatus jucundus $^{\mathrm{P}}$ & Grandi 1927b; Wiebes 1994; Lin et al. 2011 \\
\hline & Ceratosolen sp. ${ }^{p}$ & \\
\hline & Sycophaga sp.* & Bain A. unpublished data; Cruaud et al. 2011 \\
\hline & Philotrypesis sp1, sp2 & Ho 2009 \\
\hline & Sycoscapter sp. & \\
\hline & Philotrypesis spinipes & Mayr 1885; Chou and Wong 1997 \\
\hline & Philotrypesis bimaculata* & \\
\hline
\end{tabular}


Table 1 Taiwan Ficus taxa and their associated pollinating and non-pollinating wasp species (Continued)

\begin{tabular}{|c|c|c|}
\hline \multirow[t]{4}{*}{ F. variegata Blume } & Ceratosolen appendiculatus $^{p}$ & Mayr 1885; Chen and Chou 1997 \\
\hline & Apocrypta caudata* & Weiblen et al. 1995 \\
\hline & Sycophaga spinitarsus* & Mayr 1885; Rasplus J.-Y. pers. obs. \\
\hline & Sycoscapter patellaris* & $\begin{array}{l}\text { (www.figweb.org/Fig_wasps/Faunal_assemblages/Indo-Australasia/China); } \\
\text { Cruaud et al. } 2011\end{array}$ \\
\hline
\end{tabular}

The pollinating wasps are noted with a superscripted $\mathrm{p}$ whereas the wasp species not yet observed in Taiwan but reported elsewhere for these fig taxa are noted with an asterisk $(*)$. The last column displays the references of the description, the name modifications of the given species and/or the observations on these species.

were interpreted systematically. For example, the morphology of pyrena (fig seed) is different for each Ficus subgenus. Moreover, the rough surface of the Ficus from the subgenus Sycomorus can be linked with their dispersers: Fruit bats (Lee et al. 2009). Pollen shape lends insight into pollination patterns. Emarginate-ellipse and truncateellipse pollen types indicate passive pollination, whereas the truncate-rhombus pollen type indicates active pollination (Kjellberg et al. 2001).

\section{Phenology, ecology, and biology of figs and fig wasps}

Ficus ecology, particularly the interspecific mutualism between Ficus and fig wasps, began to receive attention in the early 1990s. Since then, several studies on this interspecific mutualism have been conducted (see Kjellberg et al. 2005 for review).

Prior knowledge of phenology is essential for studies on mutualism. Ficus trees differ from most of other tree species: the figs they produced host their mutualistic pollinators. Thus the Ficus reproductive phenology is not constant as other tree species (Bain et al. 2014a) that are, for example, bound to seasons (spring bloom). Numerous phenological studies of Ficus trees have been conducted in Taiwan. The subgenus Urostigma includes monoecious taxa, whereas all other subgenera in Taiwan are dioecious, having separate male and female trees. The latter produce only seeds whereas the figs of the former produce both pollen and pollen dispersers (pollinating fig wasp). Among the six subgenera in Taiwan, phenological data on all subgenera, except for the subgenus Pharmacosycea, have been collected. Finally, among the 30 Ficus taxa, only half of them have seen their phenology examined. The most studied taxon is F. erecta var. beecheyana, which has been described in six reports. In Taiwan, most phenological research has been undertaken as a part of graduate thesis work, and, therefore, is found mainly in Chinese language theses and remains unpublished in peer-reviewed journals. Nevertheless, data from this phenological research provides a strong basis for further study.

The monoecious F. microcarpa has been a study subject of four theses in Taiwan (Hsieh 1992; Chen 1994; Chen 2001; Yang 2011). Ficus microcarpa is the most studied species worldwide because of its common occurrence in cities and campuses, and its invasive status in several continents (Beardsley 1998; Farache et al 2009; Doğanlar 2012). Reports on fig production are in agreement with the aforementioned studies. Each of these three studies surveyed the F. microcarpa population on the National Taiwan University campus in different years. Fig trees were found to bear figs almost constantly throughout the year, with a decrease in fig yield observed from the beginning of autumn (Hsieh 1992; Yang et al. 2013) and some years, no figs were observed on the trees (Chen et al. 2004). In all of the aforementioned studies, the fig yield was the lowest in the winter season. Moreover, the number of crops per year varied greatly from zero to four. In addition, fig bearing in the $F$. microcarpa population was highly asynchronous as no distinct seasonal or annual pattern was identified in any of the studies. However, the genetic diversity seems to determinate the phenological diversity of the F. microcarpa trees (Yang et al. 2014).

In addition to $F$. erecta, numerous dioecious species have been surveyed to determine fig production patterns (Tzeng et al. 2003, 2005a; 2006b; Bain et al. 2014a). In northern Taiwan, dioecious species were found to have similar phenological patterns across the genus. First, male trees consistently began bearing figs at the beginning of spring every year; female trees began their fig productiona few weeks later. Second, a noticeable second production peak occurred in September and October. Third, rarer winter figs have a longer maturation period. Similar to the F. microcarpa population, other fig tree populations produced figs asynchronously. Although there was a peak production period, the production of figs was not simultaneous. The production of some trees can be delayed for a few weeks (Yao 1998; Bain et al. 2014a). After the spring crop, the populations bore a low number of figs until autumn, when the male trees again preceded the female trees with a production few weeks earlier. Finally, in winter, the trees were barest throughout Taiwan (Ho 1991; Chen 1998; Yao 1998; Chang 2003; Huang 2007; Ho et al. 2011; Chen 2012; Chiu 2012; Bain et al. 2014a).

Nevertheless, some inter- and intraspecific variations were observed. The duration of the spring crop and the 
proportion of male trees producing figs between the two crop peaks differed between species. Also the synchrony between male and female tree peaks of fig production varied greatly. Throughout most of the island of Taiwan, Ficus tree populations were found to crop during a long period in spring. A considerable proportion of male trees produce figs throughout the year (Ho 1991; Chen 1998; Yao 1998; Chang 2003; Huang 2007; Ho et al. 2011; Chen 2012; Chiu 2012; Bain et al. 2014a). At low altitudes in the extreme north, male trees have shorter spring crops than those in the south. The percentage of male trees producing figs between the two peak seasons is lower in the north than that in the south of Taiwan (Bain et al. 2014a). Finally, at higher altitudes, the production peaks of male trees during spring are extremely short and are synchronous within a population, with few male trees bearing figs between the two seasonal peaks (Wu 1996; Tzeng et al. 2003, 2006b; Bain et al. 2014a). The general island-wide pattern suggests that phenology has been shaped by environmental factors but constrained by mutualism: the short lifespan of the pollinating fig wasps requires the fig tree population to produce figs regularly (Bain et al. 2014a). Under harsh environmental conditions, male trees can produce figs only during a short period as soon as spring conditions permit, whereas under mild environmental conditions, the fig production period is extended.

In Taiwan, biochemical studies on Ficus have centered on F. pumila var. awkeotsang, which produces an edible jelly, and the two varieties (var. pumila and var. awkeotsang) with morphological features have drawn research attention. The two varieties are morphologically close (Lin et al. 1990; Tzeng 2004). Because of the economic interest in the edible jelly produced from the dried seeds of F. pumila var. awkeotsang, the biochemical and nutritional composition of the jelly has been established (Huang and Chen 1979). Later, the compounds responsible for the jelly have been identified (Liu et al. 1990). The vegetative reproduction characteristics of this species have also been reported (Liu et al. 1989).

\section{Pollinating fig wasps (Hymenoptera: Agaonidae)}

According to the phylogenetic nomenclature of Cruaud et al. (2010), we have noticed two changes in the former Taiwanese fig wasp nomenclature. First, the wasps belonging to the genus Blastophaga subgenus Valisia have been listed under the new genus Valisia. Therefore, pollinators of $F$. triloba and $F$. ruficaulis are now known as Valisia esquirolianae and V. filippina. Second, the genus Liporrhopalum has been synonymized under the genus Krabidia. Thus, all Agaonidae wasps pollinating the Ficus species from the subgenus Sycidium have been moved to the genus Krabidia (Table 1).
The study by Chen and Chou (1997) was one of the few studies that attempted to describe all pollinating wasp species from Taiwan. In their study, 24 species (seven newly described species) from eight genera were observed in Taiwan (Chen and Chou 1997). Their study still observed the 1:1 species specificity rule between fig trees and pollinating wasps. However, recently, a genetic study on the pollinating wasp species of Ficus septica concluded that it has three pollinator species with different distributions in Taiwan (Lin et al. 2011). One species was strictly limited to Orchid Island and the extreme south of Taiwan. The second species was limited only to Orchid Island and was considered rare. The third species was widely observed throughout Taiwan. Furthermore, genetic results showed weak differentiation among the fig wasp populations on the island, suggesting that the gene flow is high within the $F$. septica population in Taiwan (Lin et al. 2008). This trend was previously observed in other Ficus species, fig wasps, and other locations (Compton et al. 2000; Harrison and Rasplus 2006; Ahmed et al. 2009; Kobmoo et al. 2010). In addition, Wiebesia pumilae and Wiebesia sp., the pollinators of $F$. pumila var. pumila and F. pumila var. awkeotsang, were morphologically and genetically distinct (Lee 2009; Jiang 2011). These two wasp species have been observed in the figs of both varieties of $F$. pumila (Lu et al. 1987; Jiang 2011). In addition to taxonomic studies, since the late 1990s, studies on the population dynamics of pollinators associated with Ficus phenology have been conducted (Chen et al. 2004). The most recent phenological study on F. microcarpa in Taipei City provided data on the size of the pollinating wasp population (Yang et al. 2013). The population size varied greatly during a year. During winter, the pollination rate of figs was low whereas in summer the size of the pollinating wasp population was great and the number of foundresses could reach 19 in one single fig. These data have been used to estimate the total population of female wasps living around the studied group of F. microcarpa trees in Taipei (Yang et al. 2013). Yang et al. (2013) showed marked variation in the dynamics of the foundress population size from 0 to 40,000 within one season for the 29 studied trees. Although there was a winter trough in the number of pollinators, the pollinator population could exhibit a high recovery rate in the spring season and still reach the peak during the summer-fall season.

\section{Nonpollinating fig wasps (Hymenoptera)}

Nonpollinating fig wasps (NPFWs) are categorized in three trophic categories: the gallers that induce a gall from the plant tissue, their larva feeds on the growing gall tissue; the parasitoids that lay their eggs on other larvae which feed on the host larva; and the kleptoparasites that kill galler larvae to feed on the induced gall tissues. 
The NPFWs belong to three families (Eurytomidae, Ormyridae, and Torymidae) and seven subfamilies (Colotrechninae, Epichrysomallinae, Otitesellinae, Pteromalinae, Sycoecinae, Sycophaginae, and Sycoryctinae). The recent molecular phylogeny of the superfamily Chalcidoidea (Munro et al. 2011), which includes all of the aforementioned groups, has shown that four groups are monophyletic (Agaonidae, Epichrysomallinae, Pteromalinae, and Sycophaginae), whereas the other groups are paraphyletic. In addition, phylogenies of the subfamilies Sycophaginae (Cruaud et al. 2011) and Sycoryctinae (Segar et al. 2012) have been established. As we previously modified the names of pollinating wasp species, we here display the names of the Taiwanese species on the basis of the recent updates (Cruaud et al. 2011; Segar et al. 2012). First, the genus Apocryptophagus forms a single taxon with the genus Sycophaga, and consequently, it has been considered a junior synonym of Sycophaga and then synonymized under the genus Sycophaga (Cruaud et al. 2011). Therefore, the former Apocryptophagus wasps are currently named Sycophaga. Second, the Sycoscapter wasps once formed a group that was synonymized by Bouček (1988), all of the former names were reinstated by Segar et al. (2012): Sycoscapter, Sycoryctes, Arachonia, Sycoscapteridea, and Sycorycteridea. Nevertheless, some Sycoscapter wasps listed in Table 1 and cited from other studies may be still grouped under Sycoscapter sensu Bouček (1988).

The first and only taxonomic publication on Taiwanese NPFW addressed the F. microcarpa wasp community (Chen et al. 1999). Studies examining NPFWs have been ecological studies, such as a study of the feeding regime (galler or parasitoid) of some Sycoscapter larvae (Tzeng et al. 2008). Conversely, the ecology of Taiwanese NPFW has been thoroughly studied. First, regarding F. microcarpa, to determine whether some NPFW are galler species (gallers produce plant galls that contain a growth of tissue to feed their larvae), the fig ostiole (i.e., the only entry of the fig) was sealed to avoid the entry of the pollinating wasps (Chen et al. 2001). Without the agaonid wasps, two NPFW species laid eggs inside the fig ovules from the outside: Odontofroggatia sp. (Epichrysomallinae) and Walkerella kurandensis (Otitesellinae). Chen et al. (2001) showed that these two species were undoubtedly gallers. Second, regarding F. formosana, the exclusion of the two Sycoscapter species showed that they had a negative effect on the pollinating wasp population (Tzeng et al. 2008). In another study, Tzeng et al. (2014) showed that the fig wall thickness is a factor affecting the NPFW oviposition. Moreover, the timing of oviposition of these NPFW clearly indicated that the wasps were parasitoids.

Recent observations have shown that the NPFW species occurring on F. pedunculosa var. mearnsii belong to the genus Apocrypta (Bain, unpublished data). This genus was reported to feed on the larvae of pollinating wasps from the genus Ceratosolen (Ulenberg 1985), all pollinators of the fig subgenus Sycomorus (Rønsted et al. 2005). However, $F$. pedunculosa var. mearnsii belongs to the subgenus Ficus and is pollinated by Blastophaga wasps, but not by Ceratosolen wasps. Therefore, this observation is unexpected and should be further confirmed by studying more trees and by covering a larger area.

Finally, NPFWs are the prey of numerous ant species (Formicidae). Such ant species have been observed foraging inside figs of F. tinctoria subsp. swinhoei, F. septica, F. benguetensis, and F. subpisocarpa (Bain et al. 2014b). Ants enlarged the wasp exit hole and entered inside the figs to prey on the remaining fig wasps. On F. subpisocarpa, ants live more closely on the tree nesting inside the living branches of the tree (Bain et al. 2012). In these nests, numerous bodies of nonpollinating and pollinating wasps have been collected. Nevertheless, the foraging and hunting behaviors of the ants seem to be species dependent as wasp bodies have not been found in the nests of every ant species (Bain et al. 2012).

\section{Conclusion}

This paper presents and organizes the abundant and previously difficult-to-access research data on Ficus species and fig wasps in Taiwan. This paper compiles data from internationally accessible English language journal articles as well as local theses and dissertations, mostly in Chinese. In addition, this paper includes data from recent research conducted by the authors of this paper and presents an elaborate picture of the insect communities living on fig trees. The number and diversity of fig wasp fauna as well as the wide taxonomical range of Ficus warrant further comparative studies on the insect communities. Moreover, the high proportion of dioecious species enables investigating the sexual differences and adaptations of the two sexes. In summary, this paper provides comprehensive information on Ficus flora and wasp fauna in Taiwan, establishing a basis for understanding fig wasp survival and interspecific interaction in community ecology. Compared with other regions in the world, Taiwan provides an excellent foundation for continued ecological investigations of Ficus species and their associated communities.

\section{Competing interests \\ The authors declare that they have no competing interests.}

\section{Authors' contributions}

$A B$ carried the writing of the early draft and the gathering of the fig wasp bibliography. THY, WWJ and CLS verified all the data and conceived the final version of the review. All authors read and approved the final manuscript.

\section{Acknowledgements}

We dedicate this article to Professor Cornelis C. Berg, who passed away in August, 2012. His research provided the deep foundations of the Ficus taxonomy. We acknowledge the ANR-NSC grant (ANR-09-BLAN-0392-CSD 7, NSC 99-2923-B-002-001-MY3) for providing funding for this work. We are very 
grateful to the permission on collecting fig samples issued by the Hengchun Research Center of Taiwan Forestry Research Institute, the National Parks in Kenting and Yangmingshan. For assistance with identifying and naming fig wasps, we are deeply grateful to J-Y Rasplus and F Kjellberg. We also thank $\mathrm{H}-\mathrm{W}$ Yang, M Peng and Y-P Chiang for help uncovering the rich Taiwan fig literature.

\section{Author details}

${ }^{1}$ Institute of Ecology and Evolutionary Biology, College of Life Science, National Taiwan University, No. 1, Sec. 4, Roosevelt Rd., Taipei 10617, Taiwan. ${ }^{2}$ Centre d'Ecologie Fonctionnelle et Evolutive CEFE, UMR 5175 CNRS, 1919 route de Mende, 34293 Montpellier, France. ${ }^{3}$ Department of Forestry, National Chung-Hsing University, 250 Kuokwang Road, Taichung 40227, Taiwan. ${ }^{4}$ Department of Entomology, National Taiwan University, No. 1, Sec. 4, Roosevelt Rd., Taipei 10617, Taiwan.

\section{Received: 9 December 2014 Accepted: 27 April 2015 Published online: 16 May 2015}

\section{References}

Ahmed S, Compton SG, Butlin RK, Gilmartin PM (2009) Wind-borne insects mediate directional pollen transfer between desert fig trees 160 kilometers apart. P Natl Acad Sci USA 106(48):20342-20347, doi:10.1073/pnas.0902213106

Anstett M-C, Hossaert-McKey M, Kjellberg F (1997) Figs and fig pollinators: evolutionary conflicts in a coevolved mutualism. Trends Ecol Evol 12:94-99, doi:10.1016/S0169-5347(96)10064-1

Bai J-T (2002) The systematic wood anatomy of the Ficus (Moraceae) in Taiwan. Master Thesis. National Chung Hsing University, Taichung, Taiwan [in Chinese with English abstract]

Bain A (2012) Colonization and adaptations of Ficus in Taiwan. Dual-Degree PhD Dissertation. National Taiwan University \& Université Montpellier 2, Taipei, Taiwan \& Montpellier, France

Bain A, Chantarasuwan B, Hossaert-McKey M, Schatz B, Kjellberg F, Chou L-S (2012) A new case of ants nesting within branches of a fig tree: the case of Ficus subpisocarpa in Taiwan. Sociobiology 59(1):415-434

Bain A, Chou L-S, Tzeng H-Y, Ho Y-C, Chiang Y-P, Chen W-H et al. (2014a) Plasticity and diversity of the phenology of dioecious Ficus species in Taiwan. Acta Oecologica 57:124-134, doi:10.1016/j.actao.2013.10

Bain A, Harrison RD, Schatz B (2014b) How to be an ant on figs. Acta Oecologica 57:97-108, doi:10.1016/j.actao.2013.05.006

Beardsley JW (1998) Chalcid wasps (Hymenoptera: Chalcidoidea) associated with fruit of Ficus microcarpa in Hawai'i. P Hawaii Entomol Soc 33:19-34

Berg CC (2007) Precursory taxonomic studies on Ficus (Moraceae) for theCruaud A, Jabbour-Zahab Flora of Thailand. Thai Forest Bull Bot 35:4-28

Berg CC (2011) Corrective notes on the Malesian members of the genus Ficus (Moraceae). Blumea 56:161-164, doi:10.3767/000651911X592128

Berg CC, Corner EJH (2005) Moraceae (Ficus). In: Nooteboom HP (ed) Flora Malesiana, vol 17, Series I - Seed plants. National Herbarium Nederland, Leiden

Bouček Z (1988) Australasian Chalcidoidea (Hymenoptera): a biosystematic revision of genera of fourteen families, with a reclassification of species. C.A.B, International, Wallingford, UK

Bouček Z (1993) The genera of chalcidoid wasps from Ficus fruit in the New World. J Nat Hist 27:173-217, doi:10.1080/00222939300770071

Chang W-C (2003) Floral phenology and pollination ecology of Ficus ampelas Burm. at Chiayi. Master Thesis. National Chiayi University, Chiayi, Taiwan [in Chinese with English abstract]

Chang W-C, Lu F-Y, Ho K-Y, Tzeng H-Y (2009) Morphology of syconium of Ficus ampelas Bunn. f. Q J Forest Res 31(3):1-16 [in Chinese with English abstract]

Chen Y-R (1994) Phenology and interaction of fig wasps and Ficus microcarpa L. Master Thesis. National Taiwan University, Taipei, Taiwan [in Chinese with English abstract]

Chen Y-L (1998) Studies of phenology and interactions between Ficus irisana and its fig wasps. Master Thesis. National Chung Hsing University, Taichung [in Chinese with English abstract]

Chen Y-R (2001) Population fluctuation and community ecology of Ficus microcarpa L. and its fig wasps. PhD Dissertation. National Taiwan University, Taipei, Taiwan [in Chinese with English abstract]

Chen H-C (2012) Seasonal changes on fig production and volatiles compounds of Ficus septica Burm. f. Master Thesis. National Chung Hsing University, Taichung [in Chinese with English abstract]
Chen C-H, Chou L-Y (1997) The Blastophagini of Taiwan (Hymenoptera: Agaonidae: Agaoninae). J Taiwan Mus 50(2):113-154

Chen Y-R, Chuang W-C, Wu W-J (1999) Chalcid wasps on Ficus microcarpa L. in Taiwan (Hymenoptera: Chalcidoidea). J Taiwan Mus 52(1):39-79

Chen Y-R, Chou L-S, Wu W-J (2001) Regulation of fig wasps entry and egress: the role of ostiole of Ficus microcarpa L. Formos Entomol 21:171-182

Chen Y-R, Wu W-J, Chou L-S (2004) Synchronization of fig (Ficus microcarpa L. f.) abundance and pollinator (Eupristina verticillata: Agaoninae) population dynamics in northern Taiwan. J Natl Taiwan Mus 57(2):23-36

Chiu Y-T (2012) Phenology and population genetic variation of Ficus pedunculosa var. mearnsii. Master Thesis. National Chung Hsing University, Taichung [in Chinese with English abstract]

Chou L-Y, Wong C-Y (1997) New records of three Philotrypesis species from Taiwan (Hymenoptera: Agaonidae: Sycoryctinae). Chinese J Entomol 17:182-186

Chou L-S, Yeh H-M (1995) The pollination ecology of Ficus aurantiaca var. parvifolia. Acta Zool Taiwan 6(1):1-12

Chuang J-C (2000) Studies on the morphology of pyrenes of the fig species in Taiwan. Master Thesis, National Chung Hsing University, Taichung [in Chinese with English abstract]

Chuang J-C, Tzeng H-Y, Lu F-Y, Ou C-H (2005) Study on the morphology of pyrene of Ficus in Taiwan - Subgenus Eriosycea, Ficus and Synoecia. Q J Chinese Forest 38:1-18 [in Chinese with English abstract]

Compton SG, van Noort S (1992) Southern African fig wasps (Hymenoptera: Chalcidoidea): resource utilization and host relationships. P K Ned Akad C Biol 95(4):423-435

Compton SG, Ellwood MDF, Davis AJ, Welch K (2000) The flight heights of chalcid wasps (Hymenoptera, Chalcidoidea) in a lowland Bornean rain forest: fig wasps are the high fliers. Biotropica 32(3):515-522, doi:10.1111/j.1744-7429.2000.tb00497.x

Cook JM, Rasplus J-Y (2003) Mutualists with attitude: coevolving fig wasps and figs. Trends Ecol Evol 18:241-248, doi:10.1016/S0169-5347(03)00062-4

Corner EJH (1965) Check-list of Ficus in Asia and Australasia with keys to identification. Gard B Sing 21:1-186

Cruaud A, Jabbour-Zahab R, Genson G, Cruaud C, Couloux A, Kjellberg F, et al. (2010) Laying the foundations for a new classification of Agaonidae (Hymenoptera: Chalcidoidea), a multilocus phylogenetic approach. Cladistics 26(4):359-387, doi:10.1111/j.1096-0031.2009.00291.x

Cruaud A, Jabbour-Zahab R, Genson G, Kjellberg F, Kobmoo N, van Noort, S et al. (2011) Phylogeny and evolution of life-history strategies in the Sycophaginae non-pollinating fig wasps (Hymenoptera, Chalcidoidea). Evol Biol 11:178-192, doi:10.1186/1471-2148-11-178

Doğanlar M (2012) Occurrence of fig wasps (Hymenoptera: Chalcidoidea) in Ficus carica and F. microcarpa in Hatay, Turkey. Turk J Zool 36(5):721-724

Farache FHA, VT O, Pereira RA (2009) New occurrence of non-pollinating fig wasps (Hymenoptera: Chalcidoidea) in Ficus microcarpa in Brazil. Neotrop Entomol 38(5):683-685, doi:10.1590/S1519-566X2009000500020

Feng G, Huang D-W (2010) Description of a new species of Odontofroggatia (Chalcidoidea, Epichrysomallinae) associated with Ficus microcarpa (Moraceae) with a key to species of the genus. Zootaxa 2335:40-48

Frank SA (1985) Hierarchical selection theory and sex ratios. II. On applying the theory, and a test with fig wasps. Evolution 39(5):949-964

Galil J, Eisikowitch D (1967) On the pollination ecology of Ficus sycomorus in East Africa. Ecology 49(2):259-269

Grandi G (1916) Contributo alla conoscenza degli Agaonini (Hymenoptera, Chalcididae) di Ceylon e dell'India. B Lab Zool Portici 11:183-234 [in Italian]

Grandi G (1921) Diagnosi preliminari di Imenotteri dei fichi. Ann Mus Civ Stor Nat Genova 49:304-316 [in Italian]

Grandi G (1923) Imenotteri dei fichi dell fauna olarctica e Indo-malese. Ann Mus Civ Stor Nat Genova 51:101-108 [in Italian]

Grandi G (1926) Hyménoptères sycophiles récoltés à Sumatra et à Java par E. Jacobson Descriptions préliminaires Treubia 8:352-364 [in French]

Grandi G (1927a) Hyménoptères sycophiles récoltés aux iles Philippines par C.F. Baker, i. Agaonini. Philipp J Sci 33(3):309-329 [in French]

Grandi G (1927b) Una nuova specie di Blastophaga del Giappone. B Soc Entomol Ital 59:18-24 [in Italian]

Harrison RD (2005) Figs and the diversity of tropical rainforests. BioScience 55(12):1053-1064, doi:10.1641/0006-3568(2005)055[1053]

Harrison RD, Rasplus J-Y (2006) Dispersal of fig pollinators in Asian tropical rain forests. J Trop Ecol 22:631-639, doi:10.1017/S0266467406003488

Heraty JM, Burks RA, Cruaud A, Gibson GAP, Liljeblad J, Munro J, et al. (2013) A phylogenetic analysis of the megadiverse Chalcidoidea (Hymenoptera). Cladistics 29(5):466-542, doi:10.1111/cla.12006 
Herre EA (1985) Sex ratio adjustment in fig wasps. Science 228:896-898, doi:10.1126/science.228.4701.896

Hill DS (1967) Fig-wasps (Chalcidoidea) of Hong Kong i. Agaonidae. Zool Verh 89:1-55

Hill DS (1969) Revision of the genus Liporrhopalum Waterston, 1920 (Hymenoptera, Chalcidoidea, Agaonidae). Zool Verh 100:3-36

Ho K-Y (1987) Ecology of the pollinator, jelly fig wasp, Blastophaga pumilae Hill, with emphasis on the possibility of population establishment at low elevation. Chinese J Entomol 7:37-44 [in Chinese with English abstract]

Ho K-Y (1991) Pollination ecology of Ficus pumila L. var. awkeotsang (Makino) Corner and Ficus pumila L. var. pumila. Master Thesis. National Chung Hsing University, Taichung, Taiwan [in Chinese with English abstract]

Ho Y-C (2009) Phenology of Ficus septica in Taichung. National Chung Hsing University, Taichung [in Chinese with English abstract]

Ho Y-C, Tseng Y-H, Tzeng H-Y (2011) The phenology of Ficus septica Burm. f. at Dakeng, Taichung. Q J Forest Res 33(4):21-32 [in Chinese with English abstract]

Hsieh M-C (1992) The symbiosis between fig wasps and Ficus microcarpa L. Master Thesis, National Taiwan University, Taipei, Taiwan [in Chinese with English abstract]

Hu T-W, Liu C-C, Ho C-K (1986) Natural variation of receptacle fruits of female jelly fig (Ficus awkeotsang Makino). B Taiwan Forest Res Inst 1:139-153 [in Chinese with English abstract]

Huang J-Q (2007) The relationships between phenology and fig wasps of a dioecious Ficus tinctoria. Master Thesis. National Sun Yat-sen University, Kaohsiung, Taiwan [in Chinese with English abstract]

Huang Y-C, Chen W-P (1979) On the material plant of awkeo-jelly: Ficus awkeotsang Makino its historical review and future prospects. J Chinese Soc Hort Sci 25(4):103-111 [in Chinese]

Huang YC, Chen WP, Shao YP (1980) A study on the mechanism of gelatinization of awkeo-jelly. China Hort 4:117-126 [in Chinese]

Ishii T (1934) Fig Chacidoids of Japan. Kontyu 8(2):84-100

Janzen DH (1979) How to be a fig. Annu Rev Ecol Syst 10:13-51, doi:10.1146/ annurev.es.10.110179.000305

Jiang S-H (2011) Morphological differences between pollinating fig wasps of Ficus pumila L. var. pumila and var. awkeotsang (Makino) Corner and their asymmetric host specificity. Master Thesis. National Taiwan University, Taipei, Taiwan

Kerdelhué C, Rossi J-P, Rasplus J-Y (2000) Comparative community ecology studies on Old World figs and fig wasps. Ecology 81(10):2832-2849, doi:10.1890/0012-9658(2000)081[2832:CCESOO]2.0.CO;2

Kjellberg F, Jousselin E, Bronstein JL, Patel A, Yokoyama J, Rasplus J-Y (2001) Pollination mode in fig wasps: the predictable power of correlated traits. P Roy Soc B-Biol Sci 268:1113-1121, doi:10.1098/rspb.2000.1389

Kjellberg F, Jousselin E, Hossaert-McKey M, Rasplus J-Y (2005) Biology, ecology, and evolution of fig-pollinating wasps (Chalcidoidea, Agaonidae). In: Raman A, Schaefer W, Withers TM (eds) Biology, ecology and evolution of gall-inducing arthropods. Science Publishers, Inc., Enfield (NH) USA Plymouth (UK), pp 539-572

Kobmoo N, Hossaert-McKey M, Rasplus J-Y, Kjellberg F (2010) Ficus racemosa is pollinated by a single population of a single agaonid wasp species in continental South-East Asia. Mol Ecol 19:2700-2712, doi:10.1111/j.1365-294X.2010.04654.x

Lee H-H (2009) Genetic differentiation between Ficus pumila var. pumila and Ficus pumila var. awkeotsang and their pollinators. Master Thesis. National Taiwan University, Taipei, Taiwan

Lee Y-F, Takaso T, Chiang T-Y, Kuo Y-M, Nakanishi N, Tzeng H-Y, et al. (2009) Variation in the nocturnal foraging distribution of and resource use by endangered Ryukyu flying foxes (Pteropus dasymallus) on Iriomotejima Island, Japan. Contrib Zool 78(2):51-64

Liao J-C (1989) A taxonomic revision of the family Moraceae in Taiwan (2): Genus Ficus. Q J Chinese Forest 22(1):117-142 [in Chinese with English abstract]

Liao J-C (1995) The taxonomic revisions of the family Moraceae in Taiwan (II). Department of Forestry, College of Agriculture, National Taiwan University, Taipei, Taiwan, ROC

Lin T-P, Liu C-C, Chen S-W, Wang W-Y (1989) Purification and characterization of pectinmethylesterase from Ficus awkeotsang Makino achenes. Plant Physiol 91:1445-1453, doi:10.1104/pp. 91.4.1445

Lin T-P, Liu C-C, Yang C-Y, Huang R-S, Lee Y-S, Chang S-Y (1990) Morphological and biochemical comparison of syconium of Ficus awkeotsang and Ficus pumila. B Taiwan Forest Res Inst 5(1):37-43 [in Chinese with English abstract]

Lin R-C, Yeung CK-L, Li S-H (2008) Drastic post-LGM expansion and lack of historical genetic structure of a subtropical fig-pollinating wasp
(Ceratosolen sp. 1) of Ficus septica in Taiwan. Mol Ecol 17:5008-5022, doi:10.1111/j.1365-294X.2008.03983.x

Lin R-C, Yeung CK-L, Fong JJ, Tzeng H-Y, Li S-H (2011) The lack of pollinator specificity in a dioecious fig tree: sympatric fig-pollinating wasps of Ficus septica in southern Taiwan. Biotropica 43(2):200-207, doi:10.1111/j.1744-7429.2010.00686.x

Liu C-C, Huang R-S, Hu T-W (1989) Vegetative propagation of carrying-leaf-cutting from Ficus awkeotsang Makino. B Taiwan Forest Res Inst 4(2):71-76 [in Chinese with English abstract]

Liu C-C, Lin T-P, Huang R-S, Lee M-S (1990) Developmental biology of female syconium of Ficus awkeotsang Makino: changes in the quantities of pectinmethylesterase, pectin, methoxyl group and achene. B Taiwan Forest Res Inst 5(3):209-216 [in Chinese with English abstract]

Lu F-Y, Ou C-H, Liao C-C, Chen M-A (1987) Study of pollination ecology of climbing fig (Ficus pumila L.). B Exp Forest Natl Chung Hsing Univ 8:31-42 [in Chinese with English abstract]

Mayr G (1885) Feigeninsecten. Ver Zool-Bot Gesell 35:147-250 [in German]

Molbo D, Machado CA, Sevenster JG, Herre EA (2003) Cryptic species of fig-pollinating wasps: implications for the evolution of the fig-wasp mutualism, sex allocation, and precision of adaptation. P Natl Acad Sci USA 100:5867-5872, doi:10.1073/pnas.0930903100

Munro JB, Heraty JM, Burks RA, Hawks D, Mottern J, Cruaud A, et al. (2011) A molecular phylogeny of the Chalcidoidea (Hymenoptera). PloS One 6(11):e27023, doi:10.1371/journal.pone.0027023

Ramírez WB (1970) Host specificity of fig wasps (Agaonidae). Evolution 24(4):680-691

Rønsted N, Weiblen GD, Cook JM, Salamin N, Machado CA, Savolainen V (2005) 60 million years of co-divergence in the fig-wasp symbiosis. P Roy Soc B 272:2593-2599, doi:10.1098/rspb.2005.3249

Sata T (1934) An enumeration of Formosan Ficus. I J Trop Agr Soc Formos 6:17-28

Sata T (1944) Classification of the species of Philippine island plants. 1: on Ficus (Moraceae), a comparative study of Ficus of the Philippine and Formosa. Res. Survey 143 and 144. Bureau of Foreign Affairs, Govt. Gen. Formosa, pp 1-73

Segar ST, Lopez-Vaamonde C, Rasplus J-Y, Cook JM (2012) The global phylogeny of the subfamily Sycoryctinae (Pteromalidae): parasites of an obligate mutualism. Mol Phylogenet Evol 65(1):116-125, doi:10.1016/j.ympev.2012.05.030

Shanahan M, So S, Compton SG, Corlett RT (2001) Fig-eating by vertebrate frugivores: a global review. Biol Rev 76:529-572, doi:10.1017/S1464793101005760

Shieh W-C (1964) Studies on the pollen grain morphology in the genus Ficus in Taiwan. J Sci \& Eng 1:67-73 [in Chinese with English abstract]

Takao Y (1917) On the characteristics of pectate of Ficus pumila var. awkeotsang achenes. Res Rep Taiwan Gov-Gen Off 49:1-6 [in Japanese]

Tseng L-J, Ou CH, Lu FY, Tzeng H-Y (2000) Study of the development and morphology of syconium of Ficus formosana. Q J Taiwan Mus 22(3):55-68 [in Chinese with English abstract]

Tzeng H-Y (2004) Taxonomic study of the genus Ficus in Taiwan. PhD Dissertation. National Chung-Hsin University, Taichung, Taiwan [in Chinese with English abstract]

Tzeng H-Y, Ou C-H, Lu F-Y (2001) Morphological study on the syconia of Ficus erecta var. beecheyana. Taiwan J Forest Sci 16(4):295-306 [in Chinese with English abstract]

Tzeng H-Y, Ou CH, Lu FY (2003) Syconium phenology of Ficus erecta var. beecheyana at Hue-Sun Forest Station. Taiwan J Forest Sci 18(4):273-282 [in Chinese with English abstract]

Tzeng H-Y, Lu FY, Ou CH, Lu K-C, Tseng L-J (2005a) Phenology of Ficus formosana Maxim. at Guandaushi Forest Ecosystem. J Chinese Forest 38:377-395 [in Chinese with English abstract]

Tzeng H-Y, Lu FY, Ou CH, Lu K-C, Tseng L-J (2005b) Syconia production of Ficus formosana Maxim. at Hue-Sun Forest Station. J Forest Sci 27:45-60 [in Chinese with English abstract]

Tzeng H-Y, Chuang J-C, Ou CH, Lu FY (2006a) Study of the morphology of pyrenes of Ficus in Taiwan in the subgenera of Sycidium and Sycomorus. Taiwan J Forest Sci 18:273-282

Tzeng H-Y, Lu F-Y, Ou C-H, Lu K-C, Tseng L-J (2006b) Pollinational-mutualism strategy of Ficus erecta var. beecheyana and Blastophaga nipponica in seasonal Guandaushi Forest Ecosystem, Taiwan. Bot Stud 47:307-318

Tzeng H-Y, Tseng L-J, Ou C-H, Lu K-C, Lu F-Y, Chou L-S (2008) Confirmation of the parasitoid feeding habit in Sycoscapter, and their impact on pollinator abundance in Ficus formosana. Symbiosis 45:129-134

Tzeng H-Y, Ou CH, Lu FY, Wang CC (2009) Pollen morphology of Ficus L. (Moraceae) in Taiwan. Q J Forest Res 31:33-46 [in Chinese with English abstract] 
Tzeng H-Y, Ou C-H, Lu F-Y, Bain A, Chou L-S, Kjellberg F (2014) The effect of fig wall thickness in Ficus erecta var. beecheyana on parasitism. Acta Oecologica 57:38-43, doi:10.1016/j.actao.2013.06.007

Ulenberg SA (1985) The phylogeny of the genus Apocrypta Coquerel in relation to its hosts Ceratosolen Mayr (Agaonidae) and Ficus L. V K Ned Akad W, A Nat, Tweed Reeks 83:149-176

Wang H-Y, Hsieh C-H, Huang C-G, Kong S-W, Chang H-C, Lee H-H, et al. (2013) Genetic and physiological data suggest demographic and adaptive responses in complex interactions between populations of figs (Ficus pumila) and their pollinating wasps (Wiebesia pumilae). Mol Ecol 22:3814-3832, doi:10.1111/mec.12336

Waterston J (1921) On some Bornean fig-insects (Agaonidae - Hymenoptera Chalcidoidea). B Entomol Res 12:35-40

Weiblen G (2002) How to be a fig wasp. Annu Rev Entomol 47:299-330, doi:10.1146/annurev.ento.47.091201.145213

Weiblen GD, Flick B, Spencer H (1995) Seed set and wasp predation in dioecious Ficus variegata from an Australian wet tropical forest. Biotropica 27(3):391-394

Westwood JO (1883) Further descriptions of insects infesting figs. T Roy Entomol Soc London 31(1):29-47, doi:10.1111/j.1365-2311.1883.tb02938.x

Wiebes JT (1966) Provisional host catalogue of fig wasps (Hymenoptera, Chalcidoidea). Zool Verh 83:3-44

Wiebes JT (1977) Agaonid fig wasp from Ficus salicifolia Vahl and some related species of the genus Platyscapa Motschoulsky (Hym., Chalc.). Neth J Zool 27:209-223, doi:10.1163/002829677X00045

Wiebes JT (1980) The genus Odontofroggatia Ishii (Hymenoptera Chalcidoidea, Pteromalidae Epichrysomallinae). Zool Meded, Leiden 56:1-6

Wiebes JT (1993) Agaonidae (Hymenoptera Chalcidoidea) and Ficus (Moraceae): fig wasps and their figs, X (Wiebesia). P K Ned Akad C Biol 96:91-114

Wiebes JT (1994) The Indo-Australian Agaoninae (pollinators of figs). North-Holland, Amsterdam

Wu H-F (1996) The symbiosis between Ficus erecta Thumb var. beecheyana and Blastophaga nipponica at Yang-Ming Shan. Master Thesis. National Taiwan University, Taipei, Taiwan [in Chinese with English abstract]

Wu Z, Raven PH, Hong D (2003) Flora of China. Volume 5: Ulmaceae through Basellaceae. Missouri Botanical Garden Press, Beijing and St. Louis

Yang H-W (2011) Variation in the phenology and population interactions between Ficus microcarpa L. f. and its pollinating wasp, Eupristina verticillata. Master Thesis. National Taiwan University, Taipei

Yang H-W, Tzeng H-Y, Chou L-S (2013) Phenology and pollinating wasp dynamics of Ficus microcarpa L. f.: adaptation to seasonality. Bot Stud 54(1):e11, doi:10.1186/1999-3110-54-11

Yang H-W, Bain A, Garcia M, Chou L-S, Kjellberg F (2014) Genetic influence on flowering pattern of Ficus microcarpa. Acta Oecologica 57:117-123, doi:10.1016/j.actao.2013.12.004

Yao J-C (1998) Mutualism between Wiebesia pumilae (Hill) and Ficus pumila var. pumila L. National Taiwan University, Taipei, Taiwan [in Chinese with English abstract]

Yokoyama J, Iwatsuki K (1998) A faunal survey of fig-wasps (Chalcidoidea: Hymenoptera) distributed in Japan and their associations with figs (Ficus: Moraceae). Entomol Sci 1(1):37-46

\section{Submit your manuscript to a SpringerOpen ${ }^{\circ}$ journal and benefit from:}

- Convenient online submission

- Rigorous peer review

- Immediate publication on acceptance

- Open access: articles freely available online

- High visibility within the field

- Retaining the copyright to your article

Submit your next manuscript at $\gg$ springeropen.com 